\title{
SERKAL Syndrome
}

National Cancer Institute

\section{Source}

National Cancer Institute. SERKAL Syndrome. NCI Thesaurus. Code C123726.

An autosomal recessive condition characterized by female to male sex reversal and kidney, adrenal, and lung dysgenesis, due to mutation(s) in the WNT4 gene. 